\title{
Article
}

\section{Silicate Mineral Eutectics with Special Reference to Lithium}

\author{
Agata Stempkowska (1)
}

check for

updates

Citation: Stempkowska, A. Silicate Mineral Eutectics with Special Reference to Lithium. Materials 2021, 14, 4334. https://doi.org/10.3390/ ma14154334

Academic Editor: Myroslav Sprynskyy

Received: 25 June 2021

Accepted: 29 July 2021

Published: 3 August 2021

Publisher's Note: MDPI stays neutral with regard to jurisdictional claims in published maps and institutional affiliations.

Copyright: (C) 2021 by the author. Licensee MDPI, Basel, Switzerland. This article is an open access article distributed under the terms and conditions of the Creative Commons Attribution (CC BY) license (https:// creativecommons.org/licenses/by/ $4.0 /)$.
Department of Environmental Engineering, Faculty of Civil Engineering and Resource Management, AGH University of Science and Technology, Mickiewicza 30 Av., 30-059 Cracow, Poland; stemp@agh.edu.pl

\begin{abstract}
In this paper, the system of natural mineral alkali fluxes used in typical mineral industry technologies was analyzed. The main objective was to reduce the melting temperature of the flux systems. Particular attention was paid to the properties of lithium aluminium silicates in terms of simplifying and accelerating the heat treatment process. In this area, an alkaline flux system involving lithium was analyzed. A basic flux system based on sodium potassium lithium aluminosilicates was analyzed; using naturally occurring raw materials such as spodumene, albite and orthoclase, an attempt was made to obtain the eutectic with the lowest melting point. Studies have shown that there are two eutectics in these systems, with about $30 \%$ spodumene content. The active influence of sodium feldspar was found.
\end{abstract}

Keywords: Li-Na-K flux system; mineral eutectic; spodumene

\section{Introduction}

\subsection{Characteristics of Flux Minerals}

Lithium is a very common yet dispersed element. The largest resources are found in seawater-billions of tons of highly diluted lithium (the range is from 0.001 to $0.020 \mathrm{mg} / \mathrm{L}$ lithium), which cannot be extracted on an industrial scale [1,2]. In dissolved form, lithium has only positive effects on supplementation of its deficiencies in humans [3,4]. Minerals containing lithium in nature are formed from the transformation of pegmatites. Although about 145 minerals contain this element in smaller or larger amounts, the basic industrial raw materials are spodumene, lepidolite, petalite and amblygonite [5,6]. In industry, mainly lithium-containing aluminium silicates and sometimes lithium carbonate, obtained from lithium salines or from other lithium minerals mainly spodumene, are used. The use of lithium in the form of carbonate for high-temperature processes (firing) can cause a problem with the outgassing of the resulting $\mathrm{CO}_{2}$ [7-9]. For this reason, this paper is limited to the characterization of natural varieties of lithium aluminum silicates-spodumene.

Spodumene $\mathrm{LiAlSi}_{2} \mathrm{O}_{6}$ is one of three natural varieties of lithium aluminum silicate, the others being petalite and eucryptite. However, eucryptite occurs in nature only in one deposit Bikita, Southern Rhodesia. Eucryptite is usually synthesized and available in the $\beta$ variety $[10,11]$. Murthy and Hummel analyzed the phase system of lithium metasilicate and $\beta$-eucryptite. They found that the eutectic is formed at about $1070{ }^{\circ} \mathrm{C}[12,13]$. Spodumene is a mineral of the pyroxene group. It crystallizes in a single-crystal system in the space group $\mathrm{C} 2 / \mathrm{c}$ forming sometimes quite large crystals of whitish, gray, yellowish, lilac (kunzite) or emerald green (hiddenite) color. Spodumene melts at a temperature of about $1420{ }^{\circ} \mathrm{C}$. However, in combination with quartz, feldspars, also mica, it forms low-temperature eutectics $[14,15]$ At room temperature spodumene occurs in the $\alpha$ form. This form has a density of $3.2 \mathrm{~g} / \mathrm{cm}^{3}$. At a temperature of about $1080{ }^{\circ} \mathrm{C}$, an irreversible transition of the $\alpha$ form to $\beta$ occurs. This involves a rearrangement of the structure from a single chain to a less dense tetragonal structure. The density of $\beta$-spodumene is $2.4 \mathrm{~g} / \mathrm{cm}^{3}$. The change in density represents a $30 \%$ increase in volume $[6,16]$. 
The formation of a vitreous phase in a mineral mass requires the addition of fluxes. One of these is spodumene. With spodumene, it conducts the firing so that the following reaction occurs [17]:

$$
\begin{aligned}
& \qquad \mathrm{Li}_{2} \mathrm{O}-\mathrm{Al}_{2} \mathrm{O}_{3}-4 \mathrm{SiO}_{2}+4 \mathrm{SiO}_{2} \rightarrow \mathrm{Li}_{2} \mathrm{O}-\mathrm{Al}_{2} \mathrm{O}_{3}-8 \mathrm{SiO}_{2} \\
& \text { spodumene } \quad \text { silica } \quad \beta \text {-spodumene (solid solution) }
\end{aligned}
$$

The next minerals in the studied flux systems are alkali feldspars, these are raw materials rich in potassium $\left(\mathrm{K}_{2} \mathrm{O}\right)$, which are bound in them mainly in the form of aluminosilicates, i.e., potassium feldspars (orthoclase, microcline, sanidine, adular). For this reason, anorthite, $\mathrm{Ca}\left[\mathrm{Al}_{2} \mathrm{Si}_{2} \mathrm{O}_{8}\right]$, whose melting point is high $\left(1550{ }^{\circ} \mathrm{C}\right)$ should not be included in these raw materials although small amounts can produce eutectic. The melting point of alkali feldspars is significantly lower [18,19].

The other feldspar used as a flux is albite. Albite in nature never occurs in the pure form of sodium aluminosilicate and always contains some amount of calcium. An exception is a raw material under the name Albitte 5 (Turkey), which contains less than $1 \%$ calcium oxide and can be treated as a pure mineral $[20,21]$.

Stechiometric albite contains 11.8 wt. $\% \mathrm{Na}_{2} \mathrm{O}, 19.4$ wt. $\% \mathrm{~A}_{2} \mathrm{O}_{3}$ and $68.8 \mathrm{wt} . \% \mathrm{SiO}_{2}$. Its melting point is $1120-1200{ }^{\circ} \mathrm{C}$ and its density is $2.62 \mathrm{~g} / \mathrm{cm}^{3}$. The characteristic of albite is lower melt viscosity compared to other feldspars. In general, it is a better flux than potassium feldspar because it melts at a lower temperature; however, it causes greater deformation in the material because of congruent melting [22].

Potassium feldspar (orthoclase) $\mathrm{K}\left[\mathrm{AlSi}_{3} \mathrm{O}_{8}\right]$ melts incongruently, while sodium feldspar (albite) $\mathrm{Na}\left[\mathrm{AlSi}_{3} \mathrm{O}_{8}\right]$ melts congruently. During the firing process, the silicate melt formed at the expense of the feldspar interacts with the solid phase and partially dissolves it. This phenomenon starts at a temperature of about $1150{ }^{\circ} \mathrm{C}$. The silicate alloy leads to the expected thickening and lower porosity of the ceramic material. Feldspar raw materials characterized by the predominance of $\mathrm{K}_{2} \mathrm{O}$ to $\mathrm{Na}_{2} \mathrm{O}\left(\mathrm{K}_{2} \mathrm{O} / \mathrm{Na}_{2} \mathrm{O}\right.$ ratio should be more than 2) are most often used in technologies. These criteria are based on theoretical premises, while there is no sufficient research data in this direction, although in the case of mineral materials it is justified by the incongruent melting of potassium feldspar [22,23].

Due to the economic and environmental aspects (fossil fuel consumption, greenhouse gas emissions), research work on lowering the temperature and reducing the firing and melting time of mineral products has been going on for many years [24,25].

\subsection{Selected Thermal Parameters of Mineral Flux Systems}

The energy absorbed by a body during its heating or given off during its cooling is proportional to the product of the body mass $\mathrm{m}$ and the temperature difference of this body $\Delta \mathrm{T}$ before and after the thermal transformation. The thermal transformation ability of a material $\Delta \mathrm{Q}$ can be written in the form:

$$
\Delta \mathrm{Q}=\mathrm{c}_{\mathrm{V}} \cdot \mathrm{m} \cdot \Delta \mathrm{T}(\mathrm{J})
$$

The heat capacity of a material is called the amount of heat required to raise the temperature of a substance by one degree. The heat capacity that accrues per unit mass of a substance is called the specific heat $\mathrm{c}_{\mathrm{V}}$ (expressed in $\mathrm{J} / \mathrm{kg} \cdot \mathrm{K}$ ). This quantity is not a constant value and depends primarily on temperature. The specific heat is an additive quantity, i.e., each degree of freedom present in a system contributes to the total heat of the system. In many amorphous, glassy and crystalline substances, the specific heat increases with increasing temperature and at high temperatures [26-28].

Another quantity that characterizes materials in terms of their thermal properties is the volumetric heat capacity. Its value $b$, is calculated as the product of the specific heat, $c_{v}$ and the material density, $\rho$, of which the material is made:

$$
\mathrm{b}=\mathrm{c}_{\mathrm{v}} \cdot \rho\left(\mathrm{J} /\left(\mathrm{m}^{3} \mathrm{~K}\right)\right)
$$


Volumetric heat capacity is a measure of the amount of energy that $1 \mathrm{~m}^{3}$ of a given material will absorb while heating or give up while cooling, changing its temperature by one degree. In other words, it is the energy that raises (or lowers) the temperature of a material of unit volume by unit temperature. The materials with the highest specific density have the highest heat capacity. However, volumetric heat capacity is not sufficient to describe the ability to accumulate heat. The energy that can be accumulated per unit volume of a material is an additional parameter characterizing the effectiveness of the material accumulation phenomenon. The maximum energy that can be accumulated in a unit volume of a given material $b_{\operatorname{maxv}}$ can be described by the formula [29]:

$$
\mathrm{b}_{\operatorname{maxv}}=\mathrm{b} \cdot \Delta \mathrm{t}\left(\mathrm{J} / \mathrm{m}^{3}\right)
$$

The values of maximum volumetric energy for different rock types are in the range of $0.5-3.5 \mathrm{~kJ} / \mathrm{m}^{3}[30,31]$. The eutectic transformation during heating requires a certain heat power $\mathrm{P}$, which is given by the relation [32]:

$$
\mathrm{P}=\Delta \mathrm{Q} / \mathrm{t}(\mathrm{J} / \mathrm{s})
$$

where: $\Delta \mathrm{Q}$ - thermal transformation, $\mathrm{t}$-heating time.

The main objective of this study was to determine the image of phase transformations temperature-eutectics. The second objective was to calculate and visualize the thermal parameters of the thermal transformations of the three-component system.

\section{Materials and Methods}

In contrast to the synthetic components of the flux system, a characterization is presented for the determination of fluxing eutectics based on naturally occurring alkalines (Table 1) [33]. For naturally occurring lithium aluminosilicate minerals, temperatures can vary significantly. Therefore, it is advisable in each case to determine the eutectic points of mixtures of sodium potassium feldspar and naturally occurring lithium aluminosilicates for use as fluxes.

Table 1. Characteristic temperatures of the synthetic components of the system.

\begin{tabular}{cccc}
\hline \multirow{2}{*}{ Melting Point $\left({ }^{\circ} \mathbf{C}\right)$} & Spodumene & Albite & Microcline \\
\cline { 2 - 4 } & 1423 & 1118 & 1150 \\
\hline
\end{tabular}

Naturally occurring and commercially available raw materials containing alkali minerals were used to achieve this goal. For lithium aluminium silicate, Gresflux and micronized Concentrate were used. For Na and K feldspar, Albitte 5 nd Norfloat Spar were used. All natural mineral raw materials were supplied by Otavi minerals (Neuss, Germany). The compositions of each raw material in terms of oxides are shown in Table 2.

Base sets differing by $20 \%$ of the individual components were prepared, then the composition of the sets was condensed into the eutectic region differing by $5 \mathrm{wt} . \%$ and $10 \mathrm{wt} . \%$. as shown in Figure 1, tests were performed for both Gresfux spodumene and Concentrate.

To determine the effect of enrichment and grinding of the lithium component, enriched and micronized spodumene Concentrate with an average grain size of $d_{50}=3 \mu \mathrm{m}$ and ground spodumene Gresflux with a starting grain size of $d_{50}=180 \mu \mathrm{m}$ were introduced into the sets. Regardless of the degree of grinding, all sets were additionally homogenized for about $15 \mathrm{~min}$ in an alumina mill Fritsch pulverisette MV46 (Idar-Oberstein, Germany). The average grain size distribution of the sets did not exceed $50 \mu \mathrm{m}$. Measurements in hightemperature microscope Hesse-Instruments EM301 (Osterode am Harz, Germany) were performed on particular sets of specimens with the following assumptions; temperature increment from $80^{\circ} \mathrm{C} / \mathrm{min}$ to $650^{\circ} \mathrm{C}$ and $10^{\circ} \mathrm{C} / \mathrm{min}$ in the temperature range from $650{ }^{\circ} \mathrm{C}$ to $1500^{\circ} \mathrm{C}$. On the basis of continuous observation of the specimen and recording changes 
in its dimensions as a function of temperature, it is possible to determine the so-called characteristic temperatures (Figure 2) [14,15].

Table 2. Chemical composition and melting point of raw materials used.

\begin{tabular}{ccccc}
\hline Raw Material & Norfloat Spar & Albitte 5 & Gresflux & Concentrate \\
\hline \multicolumn{5}{c}{ Chemical Composition (wt.\%) } \\
\hline $\mathrm{SiO}_{2}$ & 65.9 & 67.1 & 68.0 & 64.95 \\
$\mathrm{Al}_{2} \mathrm{O}_{3}$ & 18.5 & 18.8 & 22.0 & 26.80 \\
$\mathrm{CaO}$ & 0.5 & 0.6 & 0.4 & 0.05 \\
$\mathrm{MgO}$ & 0.1 & 1.3 & 0.2 & 0.00 \\
$\mathrm{TiO}_{2}$ & $<0.05$ & 0.36 & - & - \\
$\mathrm{Fe}_{2} \mathrm{O}_{3}$ & 0.23 & 0.7 & 0.4 & 0.07 \\
$\mathrm{MnO}^{\mathrm{P}_{2} \mathrm{O}_{5}}$ & $<0.05$ & $<0.05$ & 0.2 & - \\
$\mathrm{Na}_{2} \mathbf{O}$ & 0.06 & 0.13 & 0.3 & 0.12 \\
$\mathbf{K}_{2} \mathbf{O}$ & $\mathbf{2 . 9}$ & $\mathbf{9 . 5}$ & $\mathbf{1 . 0}$ & $\mathbf{0 . 1 5}$ \\
$\mathbf{L i}_{2} \mathbf{O}$ & $\mathbf{1 2 . 0}$ & $\mathbf{0 . 2}$ & $\mathbf{1 . 0}$ & $\mathbf{0 . 0 8}$ \\
\hline $\mathrm{LOI}$ & - & - & $\mathbf{6 . 1}$ & $\mathbf{7 . 5 0}$ \\
\hline Melting point $\left({ }^{\circ} \mathrm{C}\right)$ & 1.02 & 1.49 & 0.29 & 0.23 \\
\hline Dominant mineral & microcline & 1360 & 1414 & 1410 \\
\hline
\end{tabular}

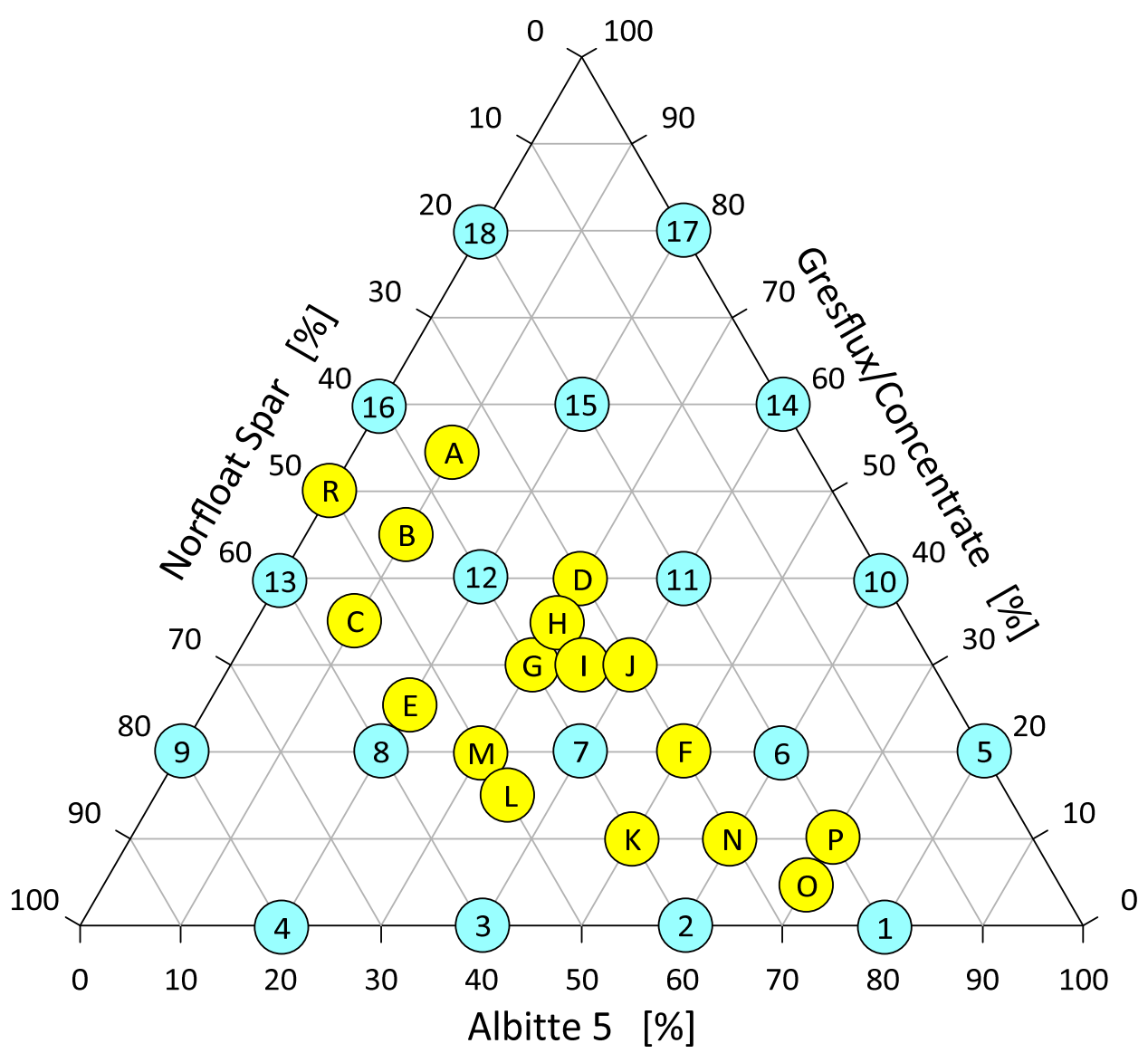

Figure 1. Distribution of samples in the spodumene-albite-microcline triangle. 


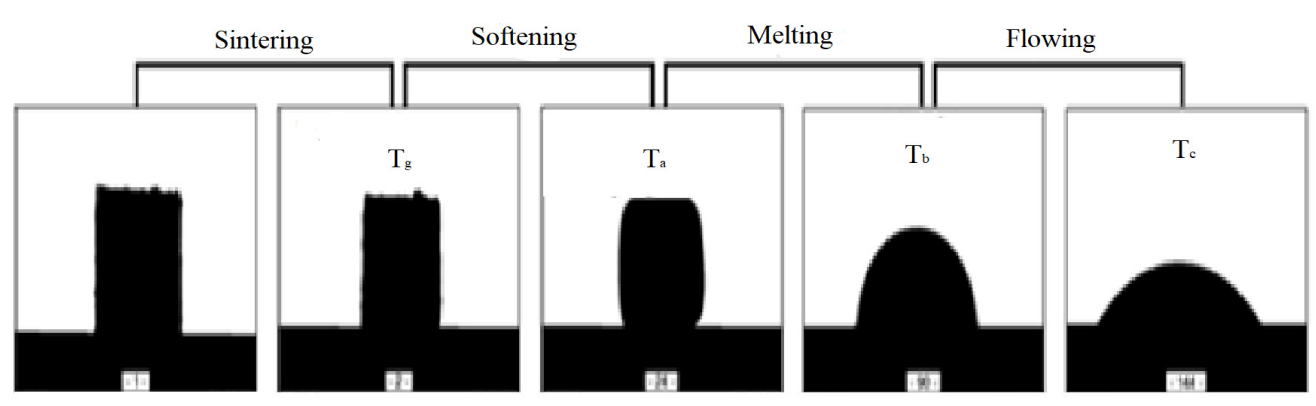

Figure 2. Method of determining characteristic temperatures and intervals in high-temperature microscopy, original state of sample 1 (spodumene Gresflux).

- shrinkage starting temperature $\mathrm{T}_{\mathrm{g}}$ (sintering)

- softening temperature $\mathrm{T}_{\mathrm{a}}$ (corner rounding-end of sintering)

- melting point $\mathrm{T}_{\mathrm{b}}$ (hemispherical effect-formation of mineral eutectic)

- spreading temperature $\mathrm{T}_{\mathrm{c}}$ (sample base $>200 \%$ or $1 / 3$ height)

By computer recording the change in the shape of the samples, it is also possible to determine:

- sintering interval (corner rounding temp. $\mathrm{T}_{\mathrm{a}}$-shrinkage temp. $\mathrm{T}_{\mathrm{g}}$ )

- melting interval (hemisphere temperature $\mathrm{T}_{\mathrm{b}}$-corner rounding temperature $\mathrm{T}_{\mathrm{a}}$ )

- flowing interval (spreading temp. $\mathrm{T}_{\mathrm{c}}$-hemisphere temp. $\mathrm{T}_{\mathrm{b}}$ ),

Investigations carried out in the high-temperature microscope belong to the standard investigations of thermal properties of materials. Not only do they allow the determination of characteristic temperatures, but also decomposition temperatures, sublimation temperatures, phase transition temperatures, etc. On the basis of continuous observation of the sample and recording changes in its dimensions as a function of temperature, it is also possible to determine the viscosity of the alloy or wetting ability with respect to the substrate [34]. Data visualization was performed with the Surfer 19 program from GoldenSoftware delivered by Gambit (Kraków, Poland). The presented test results are the average values from three measurements.

\section{Results and Discussion}

\subsection{Characteristic Temperatures}

The onset of shrinkage of individual sets during heating is the beginning of sintering and the extent to which the corners round off defines the extent of sintering. The volume change during this phenomenon is probably determined by three mechanisms. The first is related to the thermal expansion of the grains, which induces an approximate $1.5 \%$ volume swelling of the samples up to a temperature of about $1000{ }^{\circ} \mathrm{C}$. In the case of spodumene, the second swelling mechanism (about 30 vol. $\%$ ) in the temperature range $1050-1100{ }^{\circ} \mathrm{C}$ is related to the polymorphic transformation of $\alpha$ to $\beta$ spodumene $[35,36]$. In the next heating stage, shrinkage occurs due to sintering, melting and elimination of the gas phase. The temperature of the beginning of softening, i.e., rounding of corners (end of sintering) lies above the temperature of polymorphic transformation in which a significant volume change occurs. The temperature of onset of shrinkage and rounding of corners are shown in Figures 3 and 4. 

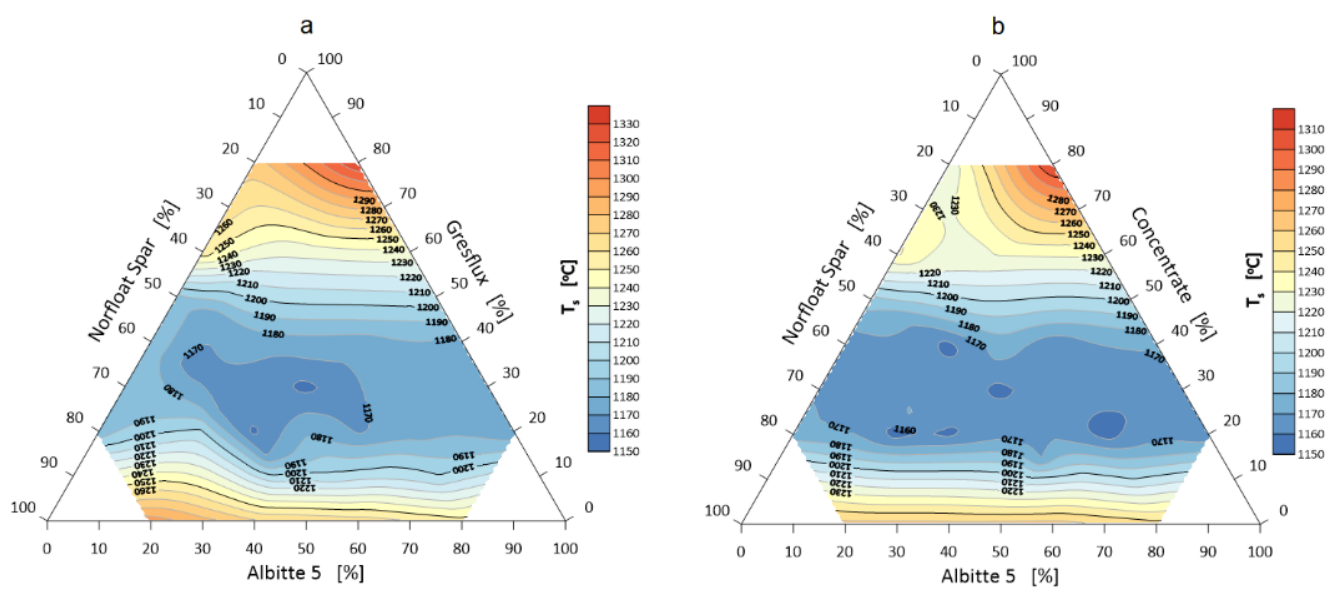

Figure 3. Shrinkage onset temperature $\mathrm{T}_{\mathrm{g}}$ of the flux system: Greflux-Albitte 5-Norfloat Spar (a), and Concentrate-Albitte 5-Norfloat (b).
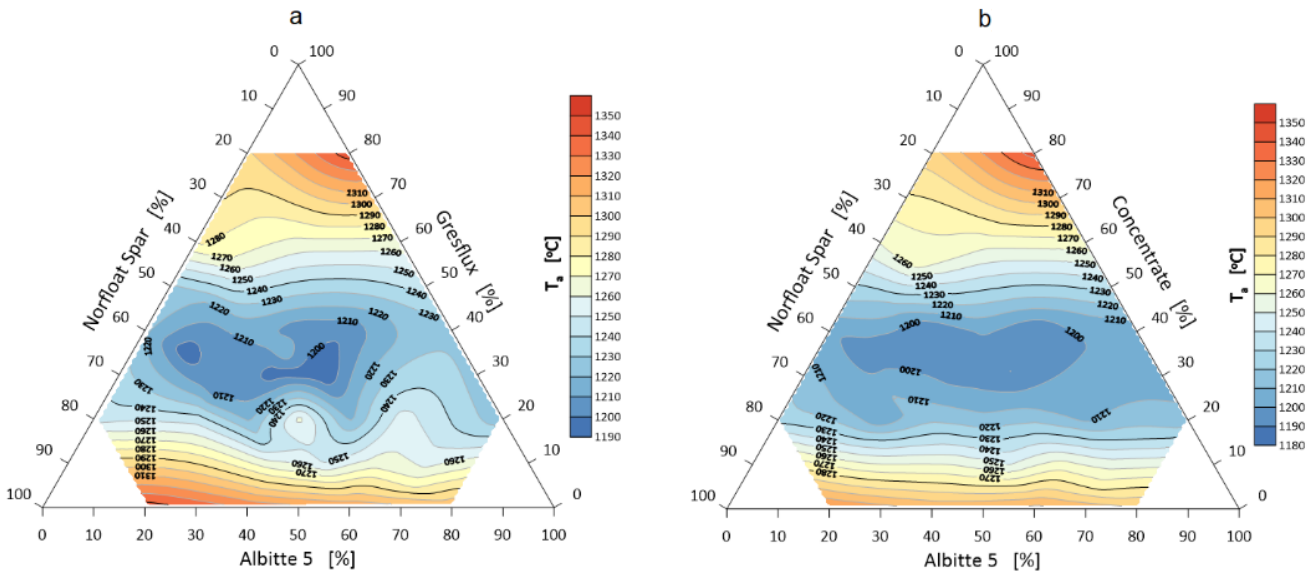

Figure 4. Rounding temperature $\mathrm{T}_{\mathrm{a}}$ of the corners of the flux system Greflux-Albitte 5-Norfloat Spar (a), and Concentrate-Albitte 5-Norfloat Spar (b).

The stage of eutectic formation of the studied system, in general, was defined as the change in the shape of the samples from the temperature of rounding of the corners, i.e., the beginning of their softening, to the formation of a hemisphere (Figure 2). The visualization of these measurements is shown in Figure 5.
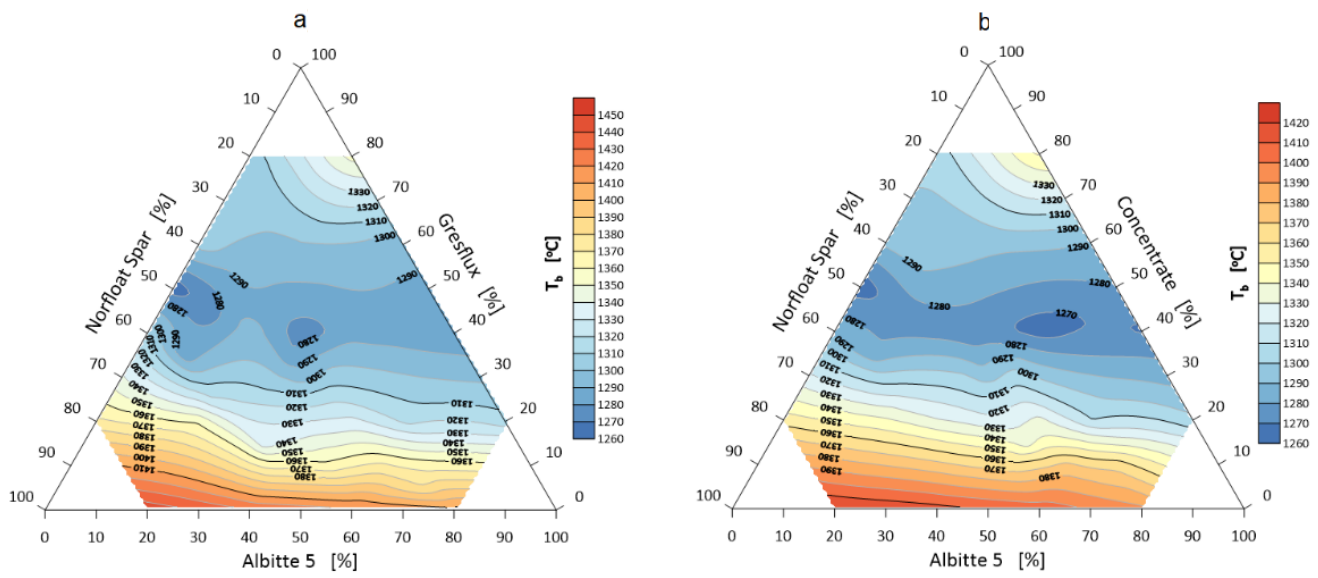

Figure 5. Melting temperature (hemisphere) $\mathrm{T}_{\mathrm{b}}$ of the flux system Greflux-Albitte 5-Norfloat Spar (a), and Concentrate-Albitte 5-Norfloat Spar (b). 
The measurements showed the first eutectic point, i.e., $1263{ }^{\circ} \mathrm{C}$ (Concentrate) and $1273^{\circ} \mathrm{C}$ (Gresflux) at compositions of $50 \mathrm{wt} . \%$ potassium feldspar and $45 \mathrm{wt} . \%$ spodumene and $30 \mathrm{wt} . \%$ potassium feldspar, $30 \mathrm{wt} . \%$ sodium feldspar and $40 \mathrm{wt} . \%$ spodumene, respectively. This applies to both micronized $\left(\mathrm{d}_{50}=3 \mu \mathrm{m}\right)$ and ground spodumene $\left(\mathrm{d}_{50}-180 \mu \mathrm{m}\right)$. A second eutectic with a higher melting point of $1382{ }^{\circ} \mathrm{C}$ (Gresflux) and $1376{ }^{\circ} \mathrm{C}$ (Concentrate) exists at the point with proportions of 50/45/5 wt.\% (B-eutectic). The study showed that the melting point of the different sets, measured as the point of hemisphere formation, did not differ significantly depending on the fineness and enrichment of the spodumene. Using micronized spodumene (Concentrate), the melting point of the system can be lowered, at most, by about $10^{\circ} \mathrm{C}$ relative to ground spodumene (Gresflux). This fact can probably be explained by the influence of the spodumene surface development and the increased amount of lithium by about $1.4 \mathrm{wt} . \%$ (Table 2) compared to the Gresflux spodumene. An active effect of sodium feldspar on the melting point of the system can be observed as well as a shift of the eutectic towards higher spodumene contents. The study shows that spodumene decreases the melting temperature of the system more than other feldspars. The characteristic spreading temperatures are shown in Figure 6.
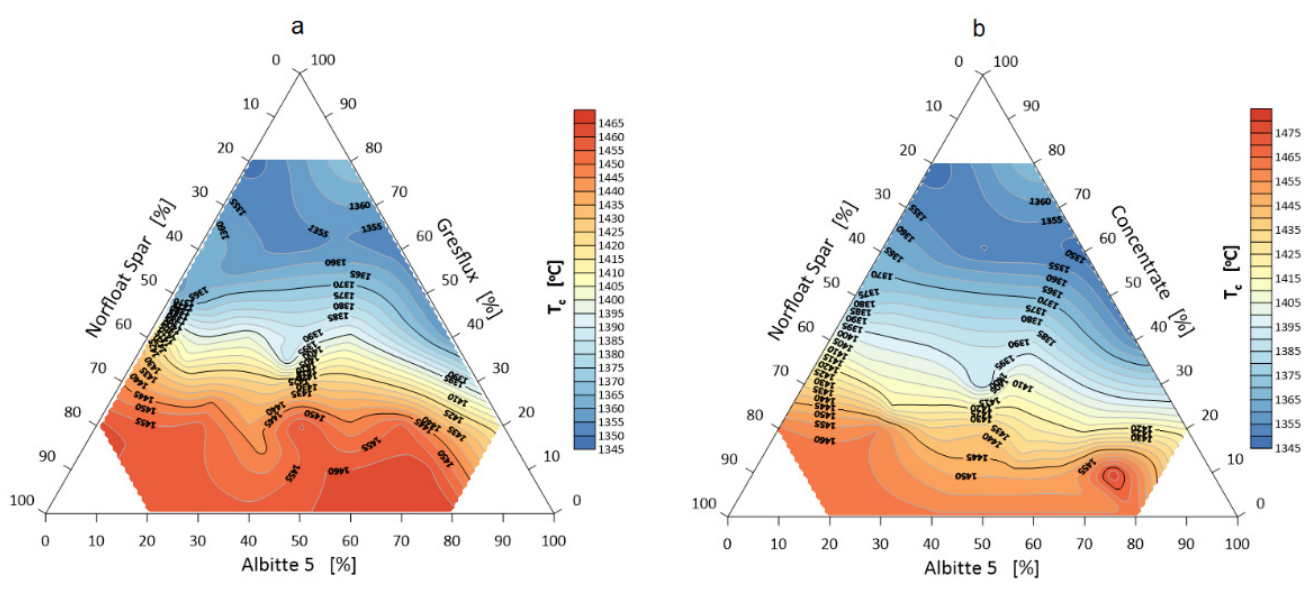

Figure 6. The beginning of the flux system spreading $T_{c}$, Greflux-Albitte 5-Norfloat Spar (a), and Concentrate-Albitte 5-Norfloat Spar (b).

It can also be observed that spodumene (both Gresflux and Concentrate) in amounts above $60 \mathrm{wt}$ \% causes significant swelling of samples up to $35 \mathrm{vol}$ \% (Figure 7).

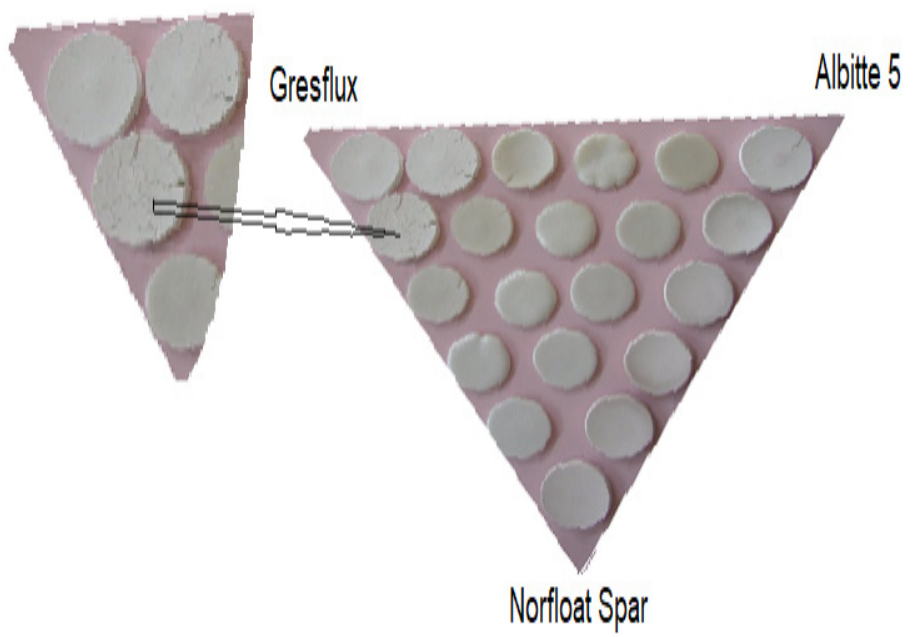

Figure 7. Swelling phenomenon of flux systems containing increased amounts of spodumene, (diameter of the pastille was $5 \mathrm{~cm}$ ). 
In the case of mineral materials, high swelling can lead to the deformation of the products. In the case of an alloy, there is no risk and the so-called softening stage is usually defined as the difference between the temperature of the onset of shrinkage and the temperature of the hemisphere. In the case of alloys, this is justified by the usually narrow transition interval between solid and liquid. From the functional point of view in terms of meltability, the reactivity of spodumene at small amounts in the set, up to $5 \mathrm{wt} . \%$, is interesting. This fact is not known so far in the literature.

\subsection{Sintering, Melting and Flowing Intervals}

The sintering interval of the sets, calculated from the temperature of the beginning of contraction to the temperature of the rounding of the corners, is of less importance with respect to flux systems. However, the smaller the interval is, the faster the system goes to the melting phase (faster time of eutectic transformation). Studies have shown that the sintering interval is shorter the more the composition of the sets approaches the eutectic point. One can also notice a greater discrepancy in the measurement results when Gresflux is used especially at a higher proportion. Probably the swelling effect caused by the polymorphic change of spodumene has a significant influence in this case. It is worth noting the two increased sintering intervals at $20 \mathrm{wt} . \%$ spodumene and 40 and $70 \mathrm{wt} . \%$ albite, respectively (Figure 8).
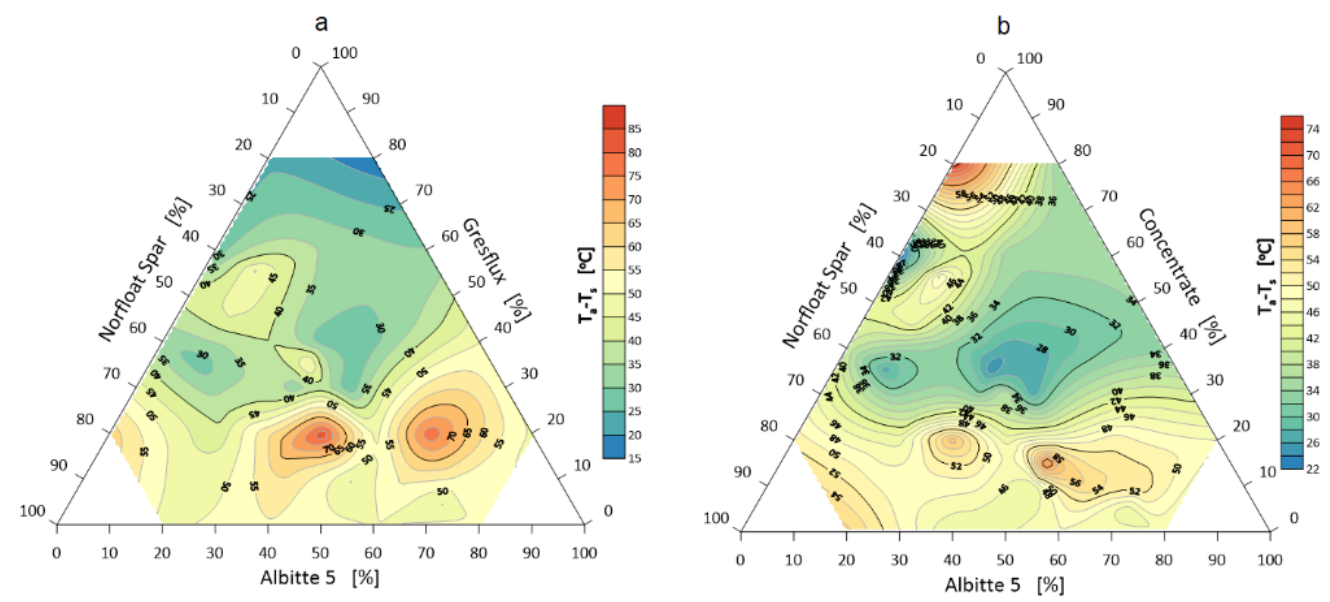

Figure 8. Sintering interval of the flux system Greflux-Albitte 5-Norfloat Spar (a), and ConcentrateAlbitte 5-Norfloat Spar (b).

Melting of the system begins when the corners of the samples are rounded. The melting interval measured by the difference between the corner rounding temperature (end of specimen shrinkage and corner rounding) and the melting temperature (hemisphere) is shown in Figure 9.

The total softening interval of the system increases slightly in favor of additional milling and enrichment. This phenomenon is related to the surface development of the micronized lithium aluminum silicate and faster reaction in the melting range. The flowing interval determines the difference between the spreading temperature and the melting temperature (hemisphere temperature). The results are visualized in Figure 10. 

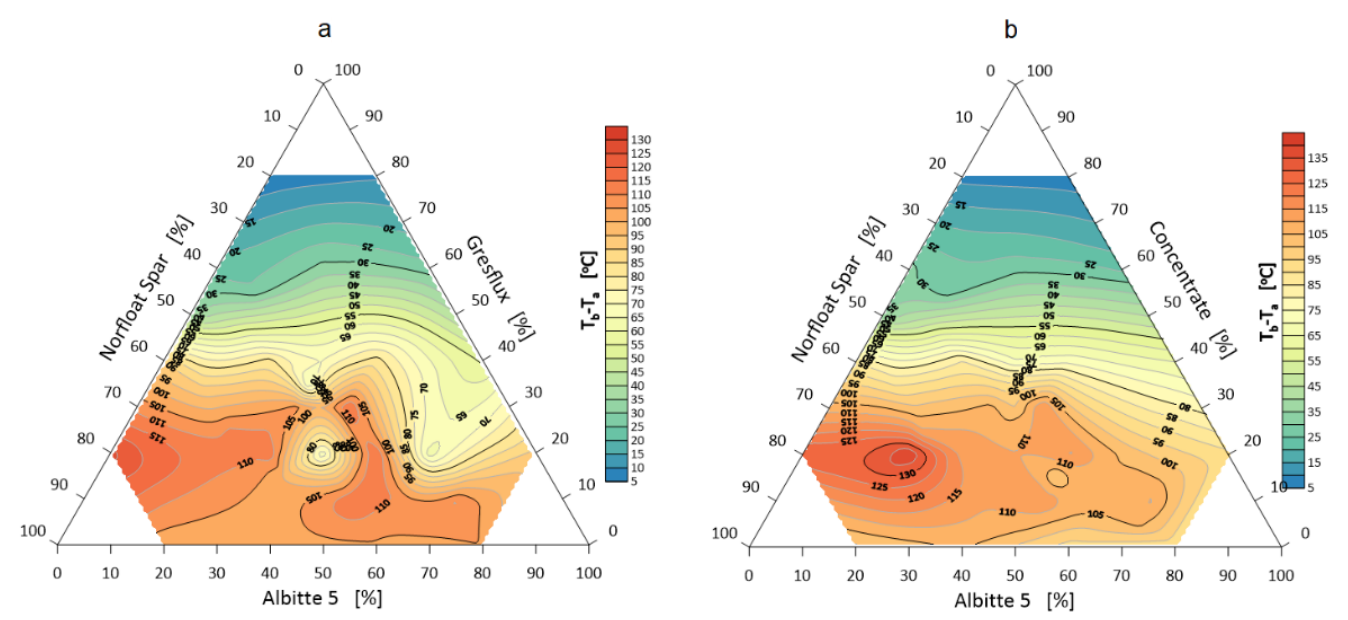

Figure 9. Melting interval of flux system Greflux-Albitte 5-Norfloat Spar (a), and Concentrate-Albitte 5-Norfloat Spar (b).
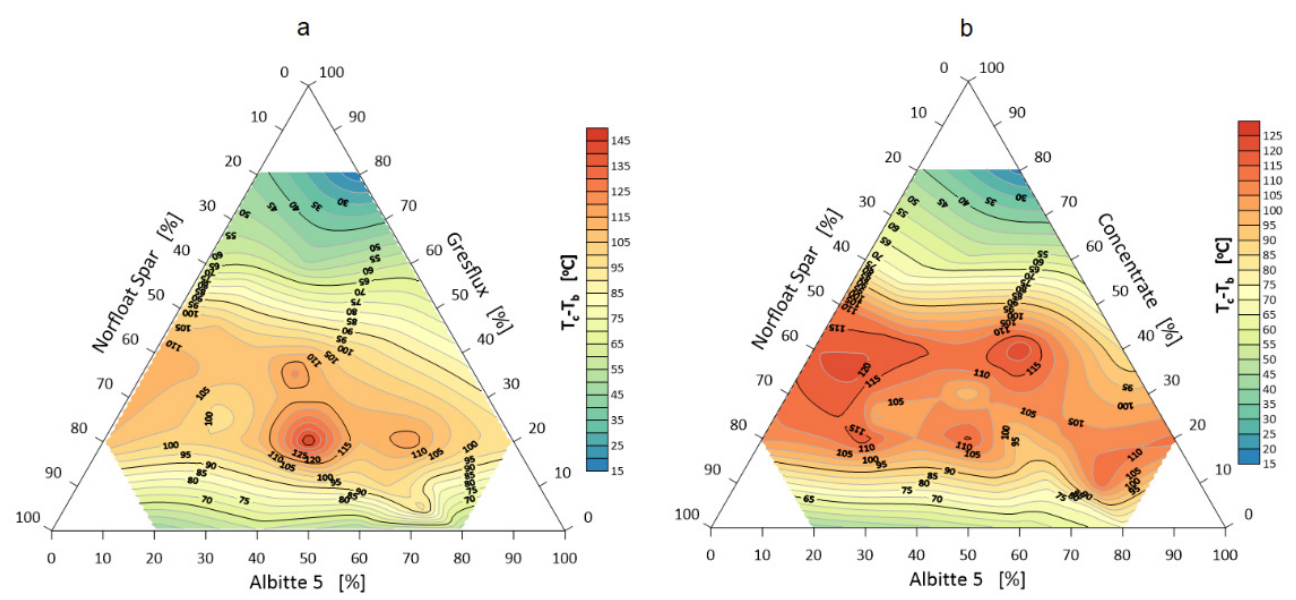

Figure 10. Flowing interval of a flux system Greflux-Albitte 5-Norfloat Spar (a), and ConcentrateAlbitte 5-Norfloat Spar (b).

Again, the greater fineness and enrichment of spodumene reduces the melt flow interval of the system by about $10^{\circ} \mathrm{C}$. The effect is particularly pronounced with increased spodumene content. Technological experience indicates that a smaller melt flow interval (lower melt viscosity) is more advantageous for the preparation of vitreous coatings as it allows better gas-phase evacuation and thus a reduction in the number of defects. In this respect, for the production of amorphous coatings, a larger spodumene grain size is not advantageous.

\subsection{Thermal Parameters of a Three-Component Flux System}

On the basis of the percentage of particular oxides contained in the raw materials (Table 2) and their tabulated $c_{v}$ values (Table 3), the resultant specific heat of the materials studied was calculated. The highest value of resultant specific heat is characterized by spodumene micronized Concentrate, it is $828.95 \mathrm{~J} / \mathrm{kgK}$, (Table 4). Specific heat is a quantity that is particularly sensitive to phase transformations of all types, i.e., a quantity whose value changes significantly near phase transformations. It carries valuable information about the nature, latent heat or critical exponent of the transformation. The incidental specific heat depends closely on the chemical composition of the raw material, which is why quality control is so extremely important. In the calculations, reference was made to the oxides of the individual elements, which build natural minerals, for the reason that the spatial structure of silicates consists of tetrahedral metal-oxygen bonding [22]. 
Table 3. Tabular-specific heat.

\begin{tabular}{cc}
\hline Oxide & $\begin{array}{c}\mathbf{c}_{\mathbf{v}} \\
(\mathbf{J} / \mathbf{k g} \cdot \mathbf{K})\end{array}$ \\
\hline $\mathrm{SiO}_{2}$ & 742 \\
$\mathrm{Al}_{2} \mathrm{O}_{3}$ & 775 \\
$\mathrm{Fe}_{2} \mathrm{O}_{3}$ & 655 \\
$\mathrm{MgO}$ & 924 \\
$\mathrm{CaO}$ & 750 \\
$\mathrm{Na}_{2} \mathrm{O}$ & 1115 \\
$\mathrm{~K}_{2} \mathrm{O}$ & 764 \\
$\mathrm{Li}_{2} \mathrm{O}$ & 1811 \\
\hline
\end{tabular}

Table 4. Calculated specific heat and density of raw materials.

\begin{tabular}{ccccc}
\hline Raw Material & Norfloat Spar & Albitte 5 & Gresflux & Concentrate \\
\hline $\begin{array}{c}\mathrm{C}_{\mathrm{V}} \\
(\mathrm{J} / \mathrm{kg} \mathrm{K})\end{array}$ & 762.63 & 772.14 & 811.79 & 828.95 \\
$\begin{array}{c}\text { density } \\
\left(\mathrm{g} / \mathrm{cm}^{3}\right)\end{array}$ & 2.58 & 2.61 & 3.1 & 3.1 \\
\hline
\end{tabular}

The materials with the highest specific density are characterized by the highest thermal storage capacity b. Volumetric heat capacity of metals with density $7000-9000 \mathrm{~kg} / \mathrm{m}^{3}$ is 1.5-3.5 MJ/( $\left.\mathrm{m}^{3} \mathrm{~K}\right)$. Natural rock formations have lower volumetric heat capacity than metals, e.g., granite-about $1.8 \mathrm{MJ} /\left(\mathrm{m}^{3} \mathrm{~K}\right)$ gabbro about $2.2 \mathrm{MJ} /\left(\mathrm{m}^{3} \mathrm{~K}\right)$, granodiorite about $2.3 \mathrm{MJ} /\left(\mathrm{m}^{3} \mathrm{~K}\right)$. Even smaller volumetric heat capacity is characterized by brick and sandabout 1.2 MJ/( $\left.\mathrm{m}^{3} \mathrm{~K}\right)[29,31,37]$. Mineral eutectics are characterized by similar values of parameter $b$ to natural rocks. Analyzing the thermal accumulation capacity $b$ contained in Tables 5 and 6, it was found that the highest value is characterized by sample 18 with a composition of $20 \mathrm{wt} \%$ albite and $80 \mathrm{wt} . \%$ spodumene, and this applies to both types of spodumene Gresflux and Concentrate. This seems to be due to the synergistic effect that sodium and lithium have on each other [14].

Table 5. Volumetric heat capacity b, and eutectic formation time, of three-component system: Gresflux spodumene, Albitte 5, Norfloat Spar, according to the compositions shown in Figure 1.

\begin{tabular}{cccccc}
\hline Set Number & $\begin{array}{c}\mathbf{b} \\
\left(\mathbf{M} \mathbf{J} / \mathbf{m}^{\mathbf{3}} \mathbf{K}\right) \mathbf{)}\end{array}$ & $\begin{array}{c}\mathbf{t} \\
\mathbf{( s )}\end{array}$ & Set Number & $\begin{array}{c}\mathbf{b} \\
\mathbf{( M j} /\left(\mathbf{m}^{\mathbf{3}} \mathbf{K}\right) \mathbf{)}\end{array}$ & $\begin{array}{c}\mathbf{t} \\
\mathbf{( s )}\end{array}$ \\
\hline 1 & 1.976 & 7794 & $\mathrm{~A}$ & 2.268 & 7002 \\
2 & 1.986 & 7656 & $\mathrm{~B}$ & 2.213 & 7182 \\
3 & 1.996 & 7620 & $\mathrm{C}$ & 2.159 & 6912 \\
4 & 2.006 & 7542 & $\mathrm{D}$ & 2.196 & 6882 \\
5 & 2.073 & 7098 & $\mathrm{E}$ & 2.111 & 6936 \\
6 & 2.083 & 7224 & $\mathrm{~F}$ & 2.092 & 6828 \\
7 & 2.093 & 7074 & $\mathrm{G}$ & 2.141 & 6858 \\
8 & 2.103 & 7056 & $\mathrm{H}$ & 2.169 & 6882 \\
9 & 2.112 & 7044 & $\mathrm{I}$ & 2.143 & 6816 \\
10 & 2.180 & 7146 & $\mathrm{~J}$ & 2.147 & 6864 \\
11 & 2.190 & 7044 & $\mathrm{~K}$ & 2.042 & 7110 \\
12 & 2.201 & 7050 & $\mathrm{~L}$ & 2.067 & 6900 \\
13 & 2.211 & 7062 & $\mathrm{M}$ & 2.093 & 6894 \\
14 & 2.290 & 7560 & $\mathrm{~N}$ & 2.049 & 7134 \\
15 & 2.301 & 7410 & $\mathrm{O}$ & 2.027 & 7272 \\
16 & 2.311 & 7428 & $\mathrm{P}$ & 2.054 & 7092 \\
17 & 2.402 & 7650 & $\mathrm{R}$ & 2.223 & 7123 \\
18 & 2.413 & 7998 & & & \\
\hline
\end{tabular}


Table 6. Volumetric heat capacity $\mathrm{b}$, and eutectic formation time, of three-component system: Concentrate spodumene, Albitte 5, Norfloat Spar, according to the compositions shown in Figure 1.

\begin{tabular}{cccccc}
\hline Set Number & $\begin{array}{c}\mathbf{b} \\
\left(\mathbf{M J} /\left(\mathbf{m}^{3} \mathbf{K}\right) \mathbf{)}\right.\end{array}$ & $\begin{array}{c}\mathbf{t} \\
\mathbf{( s )}\end{array}$ & Set Number & $\begin{array}{c}\mathbf{b} \\
\left(\mathbf{M} \mathbf{J}\left(\mathbf{m}^{3} \mathbf{K}\right) \mathbf{)}\right.\end{array}$ & $\begin{array}{c}\mathbf{t} \\
\mathbf{( s )}\end{array}$ \\
\hline 1 & 1.976 & 7578 & $\mathrm{~A}$ & 2.295 & 7746 \\
2 & 1.986 & 7566 & $\mathrm{~B}$ & 2.235 & 7632 \\
3 & 1.995 & 7602 & $\mathrm{C}$ & 2.175 & 7722 \\
4 & 2.005 & 7596 & $\mathrm{D}$ & 2.215 & 7662 \\
5 & 2.082 & 7044 & $\mathrm{E}$ & 2.121 & 7938 \\
6 & 2.091 & 6858 & $\mathrm{~F}$ & 2.102 & 7998 \\
7 & 2.102 & 6936 & $\mathrm{G}$ & 2.156 & 7800 \\
8 & 2.112 & 6864 & $\mathrm{H}$ & 2.185 & 7716 \\
9 & 2.122 & 6942 & $\mathrm{I}$ & 2.158 & 7782 \\
10 & 2.200 & 6954 & $\mathrm{~J}$ & 2.161 & 7824 \\
11 & 2.200 & 6882 & $\mathrm{~K}$ & 2.047 & 8220 \\
12 & 2.220 & 6942 & $\mathrm{~L}$ & 2.074 & 8100 \\
13 & 2.230 & 7056 & $\mathrm{M}$ & 2.102 & 7992 \\
14 & 2.320 & 7410 & $\mathrm{~N}$ & 2.053 & 8226 \\
15 & 2.331 & 7422 & $\mathrm{O}$ & 2.029 & 8286 \\
16 & 2.341 & 7392 & $\mathrm{P}$ & 2.058 & 8184 \\
17 & 2.444 & 7902 & $\mathrm{R}$ & 2.255 & 8246 \\
18 & 2.454 & 7830 & & & \\
\hline
\end{tabular}

The next step was to visualize selected thermal parameters of the spodumene-albitemicrocline ( $\mathrm{Li}-\mathrm{Na}-\mathrm{K})$ three-component system. These data are presented in Figures 11-13.

The transformation energy $\Delta Q$ of a three-component mixture depends on the mass $\mathrm{m}$, the resultant specific heat $\mathrm{c}_{\mathrm{V}}$, and the temperature difference during thermal exposure. The temperature difference is the beginning of heating of the system and reaching its melting temperature, that is phase transformation (hemisphere point of Figure 2). From a technological point of view, the lowest energy value is the most desirable-a mineral melt is obtained with the minimum possible heat input. Figure 11 shows the thermal transformation $\Delta \mathrm{Q}$ map of the system. It can be seen the fields with the lowest values at a spodumene content of about $30 \mathrm{wt} . \%$. When using micronized spodumene, the minimum energy value is about $20 \mathrm{~kJ}$ lower (Gresflux, lowest energy fields $890 \mathrm{~kJ}$, while Concentrate $870 \mathrm{~kJ})$.
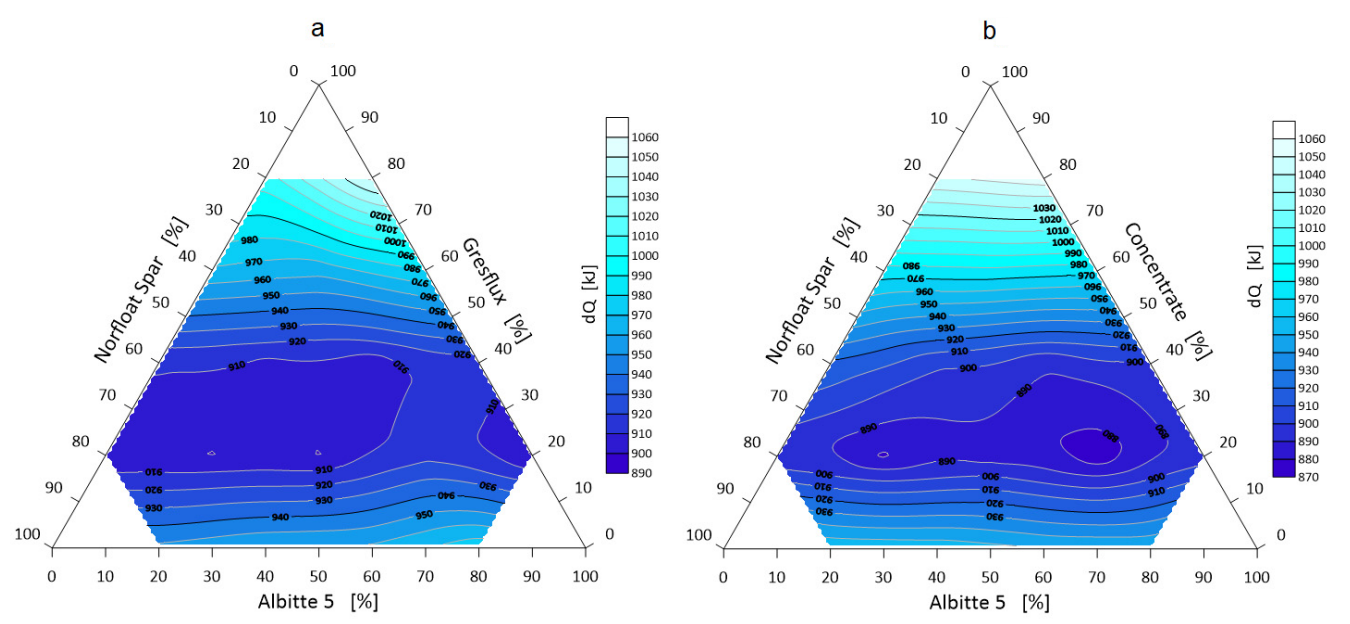

Figure 11. Transformation energy $\Delta Q$ of the three-component system, Greslux (a)/Concentrate (b) -Albitte 5-Norfloat Spar. 

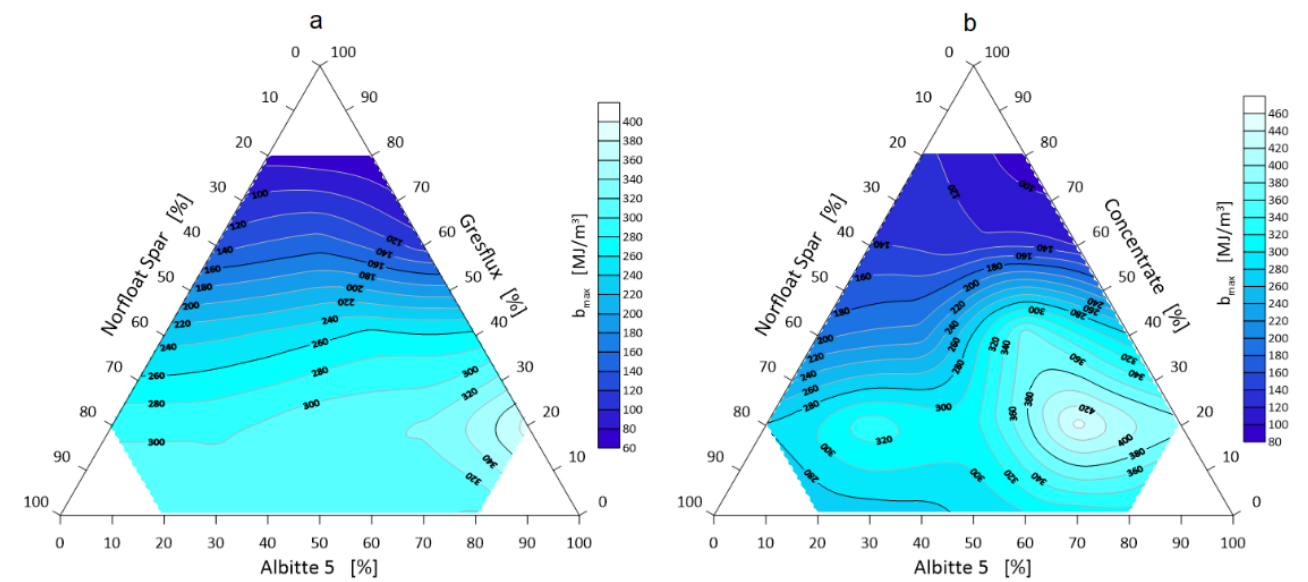

Figure 12. Maximum volumetric energy bmax of the three-component system Greslux (a) /Concentrate (b)-Albitte 5-Norfloat Spar.
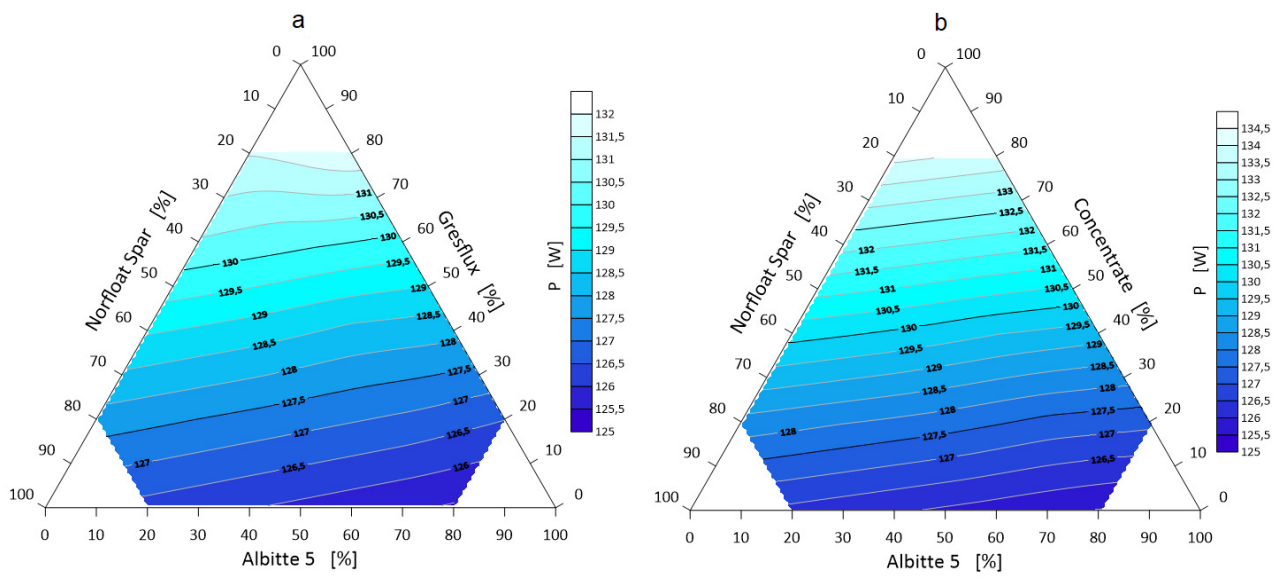

Figure 13. Thermal power P of the Greslux (a)/Concentrate (b) -Albitte 5-Norfloat Spar threecomponent mineral system.

The maximum thermal energy that the system is able to accumulate depends directly proportional to the density of the components, and to the calculated specific heat (Table 4). The highest value of the maximum volumetric energy amounting to over $440 \mathrm{MJ} / \mathrm{m}^{3}$ exactly $\left(447 \mathrm{MJ} / \mathrm{m}^{3}\right)$ was obtained in the system with a component proportion of $20 \mathrm{wt} . \%$ micronized spodumene, $20 \mathrm{wt} . \%$ microcline and $60 \mathrm{wt} . \%$ albite (point 6 in Figure 1), where the effect of grain size is clearly visible (Figure 12).

The heat power of the mineral set is linear and increasing with the spodumene content. The thermal power strictly depends on the amount of energy consumed by the system $\Delta \mathrm{Q}$ in a given time unit. The time of energy accumulation $t$ was taken as the moment of eutectic formation (Table 5), and the whole system was heated at $10{ }^{\circ} \mathrm{C} / \mathrm{min}$ in the temperature range $650-1500{ }^{\circ} \mathrm{C}$. For the micronized Concentrate spodumene, the $\Delta \mathrm{Q}$ values were several watts higher. This is due to the higher calculated specific heat (Table 4).

\section{Conclusions}

The degree of milling of spodumene concentrate lowers the eutectic temperatures of the system of spodumene-albite-microcline, but this change is marginal. In the case of the characteristic hemisphere temperature, the change is about $12^{\circ} \mathrm{C}$ and the softening temperature (rounding of corners) is about $10{ }^{\circ} \mathrm{C}$.

It was observed that micronized spodumene concrete undergoes a faster polymorphic transformation. This phenomenon causes less swelling and thus prevents the cracking of 
the samples at spodumene contents $>60 \%$. Furthermore, a significant effect of spodumene grain size on all thermal parameters of the three-component system was observed.

The characteristic temperatures of the applied natural flux raw materials are different from those of pure synthetically derived minerals (literature data). In particular, the characteristic melting temperature (hemisphere) of spodumene as a synthetic component is lower by about $7-15{ }^{\circ} \mathrm{C}$, while albite and microcline are lower by about $242{ }^{\circ} \mathrm{C}$ and $184{ }^{\circ} \mathrm{C}$, respectively.

The first eutectic melting points of the mineral system spodumene (Gresflux/Concentrate)potassium feldspar (Norfloat Spar)-sodium feldspar (Albitte 5) occurred at $1275^{\circ} \mathrm{C}$ (Gresflux) and $1263{ }^{\circ} \mathrm{C}$ (Concentrate) with proportions of $40 / 30 / 30 \mathrm{wt} . \%$ (A-eutectic). A second eutectic with a higher melting point of $1382^{\circ} \mathrm{C}$ (Gresflux) and $1376^{\circ} \mathrm{C}$ (Concentrate) exists at the point with proportions of 50/45/5 wt. $\%$ (B-eutectic).

The fields of the lowest values of the energy of eutectic transformation are observed when the spodumene content (of both types) is about $30 \mathrm{wt} . \%$. However, the maximum thermal energy accumulated by the system is $447 \mathrm{MJ} / \mathrm{m}^{3}$, which refers to the system with micronized spodumene with the composition of $20 \mathrm{wt} . \%$ Concentrate, $20 \mathrm{wt} . \%$ Norfloat and $60 \mathrm{wt} . \%$ Albitte 5.

Visualizations of selected thermal parameters of three-component mixtures clearly show that the formation of eutectic is the result of many parameters, however, strictly depends on the components' proportions and their chemical composition.

The next stage of work will be the study of high-temperature viscosity of mineral eutectics, and the behavior of Li-Na-K system in the presence of raw materials containing $\mathrm{Ca}$ and $\mathrm{Mg}$.

Funding: This research received no external funding.

Institutional Review Board Statement: Not applicable.

Informed Consent Statement: Not applicable.

Data Availability Statement: The data presented in this study are available on request from the corresponding author.

Conflicts of Interest: The authors declare no conflict of interest.

\section{References}

1. Lenntech, B.V. Lithium and Water Reaction Mechanisms, Environmental Impact and Health Effects. 2018. Available online: http:/ / www.lenntech.com/periodic/water/lithium/lithium-and-water.htm (accessed on 22 June 2018).

2. Service, R. Seawater could provide nearly unlimited amounts of critical battery material. Science 2020. [CrossRef]

3. Brown, E.E.; Gerretsen, P.; Pollock, B.; Graff-Guerrero, A. Psychiatric benefits of lithium in water supplies may be due to protection from the neurotoxicity of lead exposure. Med. Hypotheses 2018, 115, 94-102. [CrossRef] [PubMed]

4. Memon, A.; Rogers, I.; Fitzsimmons, S.M.D.D.; Carter, B.; Strawbridge, R.; Hidalgo-Mazzei, D.; Young, A.H. Association between naturally occurring lithium in drinking water and suicide rates: Systematic review and meta-analysis of ecological studies. Br. J. Psychiatry 2020, 217, 667-678. [CrossRef] [PubMed]

5. Jaskula, B.W. Mineral Commodity Summaries 2019; United States Geological Survey: Reston, VA, USA, 2019 ; pp. 98-99.

6. Dessemond, C.; Lajoie-Leroux, F.; Soucy, G.; Laroche, N.; Magnan, J.-F. Spodumene: The Lithium Market, Resources and Processes. Minerals 2019, 9, 334. [CrossRef]

7. Timoshevskii, A.N.; Ktalkherman, M.G.; Emel'Kin, V.A.; Pozdnyakov, B.A.; Zamyatin, A.P. High-temperature decomposition of lithium carbonate at atmospheric pressure. High Temp. 2008, 46, 414-421. [CrossRef]

8. Liu, W.; Chu, G.W.; Li, S.C.; Bai, S.; Luo, Y.; Sun, B.C.; Chen, J.F. Preparation of lithium carbonate by thermal decomposition in a rotating packed bed reactor. Chem. Eng. J. 2019, 377, 119929. [CrossRef]

9. Shi, L.; Qu, T.; Liu, D.; Deng, Y.; Yang, B.; Dai, Y. Process of Thermal Decomposition of Lithium Carbonate. In Materials Processing Fundamentals; Lee, J., Wagstaff, S., Lambotte, G., Allanore, A., Tesfaye, F., Eds.; The Minerals, Metals \& Materials Series; Springer: Cham, Switzerland, 2020. [CrossRef]

10. Garrett, D.E. Handbook of Lithium and Natural Calcium Chloride; Elsevier: New York, NY, USA, 2004.

11. Kenfack, F.; Vieth, S. Synthesis of eucryptite spheres. J. Mater. Sci. 2008, 43, 4644-4651. [CrossRef]

12. Murthy, M.K.; Hummel, F.A. Phase equilibria in the system lithium metasilicate-eukryptit. J. Am. Ceram. Soc. 1954, 37, 14-17. [CrossRef] 
13. Suárez, M.; Fernández, A.; Díaz, L.A.; Sobrados, I.; Sanz, J.; Borrell, A.; Palomares, F.J.; Torrecillas, R.; Moya, J.S. Synthesis and sintering at low temperature of a new nanostructured beta-Eucryptite dense compact by spark plasma sintering. Ceram. Int. 2020, 46, 18469-18477. [CrossRef]

14. Cioch, A.; Izak, P.; Stempkowska, A.; Thiery, D. Właściwości stopu układu: Spodumen-skaleń potasowy-skaleń sodowy. Szkło Ceram. 2009, 1, 29-32.

15. Izak, P.; Cioch, A.; Thiery, D. Charakterystyka układu spodumen-skaleń potasowy-skaleń sodowy. Ceramika 2008, 103, 1201-1206.

16. Kunasz, I.A. Lithium Resources. In Industrial Minerals and Rocks; SME (Society Mining Metallurgy and Exploration): Englewood, CO, USA, 2006; pp. 599-614.

17. Dessemond, C.; Soucy, G.; Harvey, J.-P.; Ouzilleau, P. Phase Transitions in the $\alpha-\gamma-\beta$ Spodumene Thermodynamic System and Impact of $\gamma$-Spodumene on the Efficiency of Lithium Extraction by Acid Leaching. Minerals 2020, 10, 519. [CrossRef]

18. Lewicka, E. Podaż surowców skaleniowych w Polsce ze źródeł krajowych i zagranicznych w świetle potrzeb rynku. Przeglą Geol. 2017, 65, 392-399.

19. Sokolář, R.; Keršnerová, L.; Šveda, M. The effect of different fluxing agents on the sintering of dry pressed porcelain bodies. J. Asian Ceram. Soc. 2017, 5, 290-294. [CrossRef]

20. Bozdoğan, I.; Göknel, I. Turkish feldspar. Ceramika/Ceramics 2004, 84, 115-118.

21. Wyszomirski, P.; Gacki, F.; Szydłak, T. Turkish feldspar raw materials in polish production of ceramic tiles. Gospod. Surowcami Miner./Miner. Resour. Manag. 2012, 28, 5-18. [CrossRef]

22. Handke, M. Krystalochemia Krzemianów; Wydawnictwa AGH: Kraków, Poland, 2008.

23. Wyszomirski, P.; Galos, K. Surowce Mineralne i Chemiczne Przemystu Ceramicznego; AGH Uczelniane Wydawnistwo NaukowoDydaktyczne: Kraków, Poland, 2007.

24. Xia, J.; Geng, R.; Chen, Z. The Effect of K-feldspar and Silica as Fluxing Agent on the Production Process of Phosphorus Furnace. Silicon 2018, 11, 233-239. [CrossRef]

25. Peng, L.; Qin, S. Sintering behavior and technological properties of low-temperature porcelain tiles prepared using a lithium ore and silica waste. Minerals 2019, 9, 731. [CrossRef]

26. Grimvall, G. Thermophysical Properties of Materials; North-Holland: Amsterdam, The Netherlands, 1986.

27. Kalinowski, E. Termodynamika; Wydawnictwo Politechniki Wrocławskiej: Wrocław, Poland, 1994.

28. Więckowski, J. Właściwości Cieplne i Magnetyczne Wybranych Związków Kobaltu o Strukturze Warstwowej. Ph.D. Thesis, Polska Akademia Nauk, Warszawa, Poland, 2013.

29. Szargut, J. Termodynamika Techniczna; Wydawnictwo Politechniki Śląskiej: Gliwice, Poland, 2000.

30. Stempkowska, A.; Izak, P.; Mastalska-Popławska, J.; Staszewska, M. The analysis of thermal properties of selected rock materials by thermovision methods. J. Pol. Miner. Eng. Soc. 2018, 20, 337-344.

31. Stempkowska, A.; Mastalska-Popławska, J.; Izak, P.; Wójcik, Ł.; Gawenda, T.; Karbowy, M. Research on the Thermal Properties of Fireplace Concrete Materials Containing Various Mineral Aggregates Enriched by Organic and Inorganic Fibers. Materials 2021, 14, 904. [CrossRef]

32. Zergadło, B.; Halicka, A. Analiza właściwości cieplnych betonu z kruszywem z odpadów ceramiki sanitarnej. Bud. Archit. 2011, 9, 39-49.

33. Boyd, J.E. Pyrometric Properties of Spodumene-Felspar Mixtures. J. Am. Ceram. Soc. 1938, 21, 385-388. [CrossRef]

34. Amarante, M.M.; Botelho de Sousa, A.; Machado Lite, M. Technical note processing a spodumene ore to obtain lithium concentrates for addition to glass and ceramic bodies. Miner. Eng. 1999, 12, 433-436. [CrossRef]

35. Abdullah, A.A.; Oskierski, H.C.; Altarawneh, M.; Senanayake, G.; Lumpkin, G.; Dlugogorski, B. Phase transformation mechanism of spodumene during its calcination. Miner. Eng. 2019, 140, 105883. [CrossRef]

36. Saalfeld, H. Struktur und Ausdehnungsverhalten von Li-Al-Silikate. Ber. Dtsch. Keram. Ges. 1961, 38, $281-286$.

37. Schön, J. Physical Properties of Rock. Dev. Pet. Sci. 2015, 65, 369-414. 